\title{
Medical waste-management practices vary across Canada
}

$\mathrm{C}$ ondoms and syringes mixed with household waste and then exported from the United Kingdom to Brazil for recycling. Scalpels and other sharps left in heaps outside of hospitals. Effluents from health facilities "discharged directly in rivers and other water streams." Hazardous materials incinerated at inadequate temperatures. Deaths in Brazil, Algeria, Morocco and Mexico caused by improper disposal of radiotherapy materials.

As disturbing as the litany of unsound world practices in the disposal of medical waste was United Nations Special Rapporteur Calin Georgescu's conclusion that "only a limited number of countries has developed, or is in the process of developing, a national regulatory framework" to handle the mountain of medical waste now being produced by the world's health facilities (www2 .ohchr.org/english/bodies/hrcouncil/docs /18session/A-HRC-18-31_en.pdf).

How does Canada stack up?

Well, medical waste disposal certainly doesn't fall under the rubric of a national regulatory framework, but that's in part a product of proverbial Canadian jurisdictional splits on matters of health.

And while not all provinces have regulations governing the handling and disposal of medical waste, environmental experts say most jurisdictions do a reasonable job of disposal and aren't party to the sort of egregious abuses witnessed in some other nations.

For the most part, Canada doesn't take as heavy a regulatory approach toward hazardous medical waste as the United States, says Colin Rasmussen, a cell biologist and patent attorney with legal practices in both Saskatchwan and California. "Canada I don't think has really been jumping on the bandwagon of regulation because I suspect typically things get regulated when there's this perception that it needs to be regulated and I don't think there's been this perception that it's been a big problem.'

The majority of provinces rely on umbrella legislation governing all waste material to regulate the handling the medical waste. Only Quebec appears to have biomedical waste-specific legislation (www2.publicationsduquebec.gouv .qc.ca/dynamicSearch/telecharge.php ?type=3\&file=/Q_2/Q2R12_A.htm).

Some provinces, though, have guidelines and targets for the management of biomedical waste. In whatever form, regulations or guidelines, most

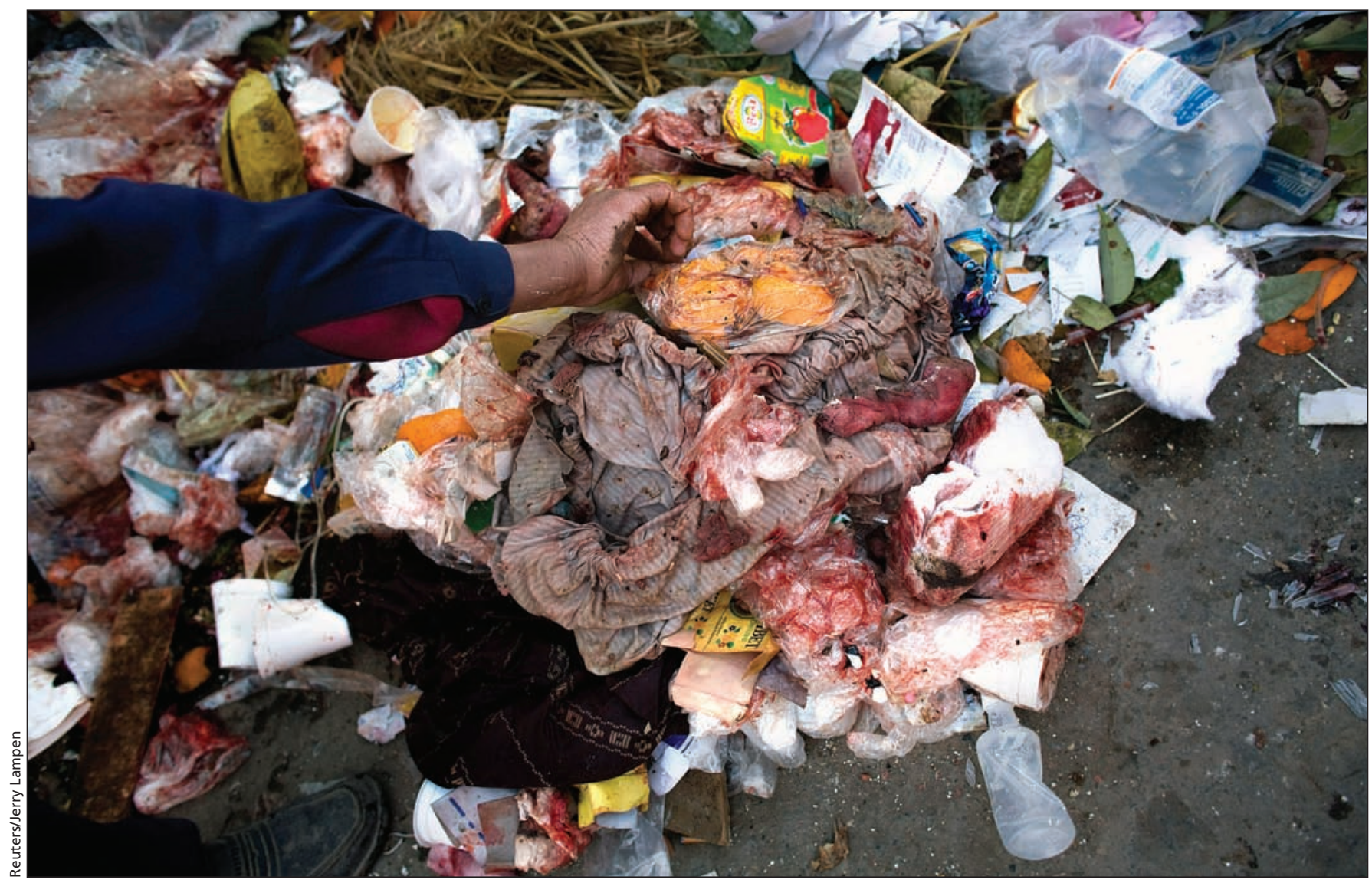

A man sifts through medical waste at a garbage dump in central Lahore, Pakistan. 
provinces also appear to aim their approach at achieving minimum national standards for handling biomedical waste that were developed by the Canadian Council of Ministers of the Environment in 1992 (www.ccme .ca/assets/pdf/pn_1060_e.pdf).

Whatever the legal foundation used to regulate medical waste, it has generally resulted in some manner of requirement that hazardous medical waste be sterilized prior to disposal at a landfill. That's the case in Ontario, says Kate Jordan, a spokesperson for the Ontario Ministry of the Environment. She adds that sharps, such as needles and syringes, have to be put into containers and treated by either autoclaving or hydroclaving.

"Once they've been treated they're no longer considered biomedical waste because they've been properly sanitized so they don't pose any health risk," Jordan says. But the biomedical waste must nevertheless be segregated from domestic waste and buried separately, "as a general best management practice," she adds.

For the most part, Canada's hospitals appear to moving away from onsite incinerators toward centralized provincial facilities for the actual sterilization of biomedical waste.

In British Columbia, Alberta, New Brunswick and Nova Scotia, all hazardous biomedical waste is taken to a third-party vendor or disposed of at a centralized facility.

That's part of a nation-wide trend to take incineration out of the hands of hospitals, Environment Canada spokesperson Henry Lau writes in an email. "In their place, commercial medical waste incineration facilities have been established to handle the medical waste generated over a larger geographic area."

Lau adds that it is up to each province to implement standards recommended by the Canadian Council of Ministers of the Environment, which indicate that land- fills should only accept waste that has been decontaminated; that facilities should prearrange required volumes with landfill operators; that facilities should provide evidence of treatment of their waste before sending it to landfills; that decontaminated waste should be buried immediately or in compliance with a designated schedule; and that the waste should be covered with earth or other waste to prevent direct contact with landfill equipment.

But it's unclear how often governments inspect practices, incineration facilities or landfills. Kathleen Range, spokesperson for Alberta Health and Wellness says the "collection and segregation of biomedical wastes at the place of generation are carried out in accordance with waste-management procedures outlined in regional infection control procedures developed by institutions or Alberta Health Services."

Some suggest that medical waste disposal in Canada may rely too heavily on goodwill rather than strict regulation, and that there is a need for a more national approach.

"To me it's a continuum," says Rachel Bard, chief executive officer for the Canadian Nurses Association. The federal government has a leadership role to set benchmarks, the provinces must enact legislation to achieve those targets, and health care facilities must have the processes in place to ensure implementation and compliance, she says. "It's a multi-prong approach. I think there's responsibility at all levels."

Georgescu's report to the UN recommended that all countries develop comprehensive waste-management strategies, including specific definitions of what constitutes waste, clearly-defined duties and responsibilities for each player in the waste-management process, the identification of a "national authority responsible for overseeing the implementation of the law and its enforcement," and specific penalties for contravention.
He also urged:

- "Measures to raise awareness of the problems, especially among policymakers and communities living in the vicinity of sites where medical waste is incinerated or landfilled. Non-governmental organizations working in the field of public health or environmental protection should include the promotion of sound health-care waste management in their advocacy and conduct programmes and activities that contribute to sound health-care waste management."

- The adoption of strict occupational health and safety frameworks within hospitals to protect health care works, complete with "adequate human, technical and financial resources to national authorities responsible for its enforcement," as well as proper training of staff who must handle medical waste, and proper protection for workers, such as vaccinations and the provision of appropriate equipment.

- That governments allocate "adequate financial resources to all public and private institutions and bodies responsible for the safe and environmentally sound management of health-care waste."

- That countries develop and adopt comprehensive health care wastemanagement plans, including policies to separate hazardous waste at source and policies for the proper handling, transportation, storage and disposal of medical waste. - Erin Walkinshaw, Mississauga, Ont.

\section{CMAJ 2011. DOI:10.1503/cmaj.109-4032}

Editor's note: First of a two-part series

Part II: Too much of a good thing? (www.cmaj.ca/lookup/doi/10.1503 /cmaj.109-4033). 